\section{About the Author}

Dr. Shi is a researcher at the School of Life Sciences and Engineering, Foshan University, Foshan, Guangdong Province, China. His research interests include emerging mosquitoborne infectious diseases.

\section{References}

1. Yang T, Li R, Hu Y, Yang L, Zhao D, Du L, et al. An outbreak of Getah virus infection among pigs in China, 2017. Transbound Emerg Dis. 2018;65:632-7. http://dx.doi.org/10.1111/tbed.12867

2. Yago K, Hagiwara S, Kawamura H, Narita M. A fatal case in newborn piglets with Getah virus infection: isolation of the virus. Nippon Juigaku Zasshi. 1987;49:989-94. http://dx.doi.org/10.1292/ jvms1939.49.989

3. Nemoto M, Bannai H, Tsujimura K, Kobayashi M, Kikuchi T, Yamanaka T, et al. Getah virus infection among racehorses, Japan, 2014. Emerg Infect Dis. 2015;21:883-5. http://dx.doi.org/10.3201/ eid2105.141975

4. Li Y, Fu S, Guo X, Li X, Li M, Wang L, et al. Serological survey of Getah virus in domestic animals in Yunnan Province, China. Vector Borne Zoonotic Dis. 2019;19:59-61. http://dx.doi.org/10.1089/ vbz.2018.2273

5. Li XD, Qiu FX, Yang H, Rao YN, Calisher CH, Calisher CH. Isolation of Getah virus from mosquitos collected on Hainan
Island, China, and results of a serosurvey. Southeast Asian J Trop Med Public Health. 1992;23:730-4.

6. Marchette NJ, Rudnick A, Garcia R. Alphaviruses in peninsular Malaysia: II. Serological evidence of human infection. Southeast Asian J Trop Med Public Health. 1980;11:14-23.

7. Shi N, Liu H, Li LX, Hu B, Zhang L, Zhao CF, et al. Development of a TaqMan probe-based quantitative reverse transcription PCR assay for detection of Getah virus RNA. Arch Virol. 2018;163: 2877-81. http://dx.doi.org/10.1007/s00705-018-3927-2

8. Kuwata R, Shimoda H, Phichitraslip T, Prasertsincharoen N, Noguchi K, Yonemitsu K, et al. Getah virus epizootic among wild boars in Japan around 2012. Arch Virol. 2018;163:2817-21. http://dx.doi.org/10.1007/s00705-018-3897-4

9. Bannai H, Nemoto M, Niwa H, Murakami S, Tsujimura K, Yamanaka T, et al. Geospatial and temporal associations of Getah virus circulation among pigs and horses around the perimeter of outbreaks in Japanese racehorses in 2014 and 2015. BMC Vet Res. 2017;13:187. http://dx.doi.org/10.1186/s12917-017-1112-6

10. Li YY, Liu H, Fu SH, Li XL, Guo XF, Li MH, et al. From discovery to spread: the evolution and phylogeny of Getah virus. Infect Genet Evol. 2017;55:48-55. http://dx.doi.org/10.1016/ j.meegid.2017.08.016

Address for correspondence: Hao Liu, Foshan University, School of Life Sciences and Engineering, 18 Jiangwan First Rd, Chancheng District, Foshan, Guangdong 528000, China; email: liuhao_lh@hotmail.com

\title{
Correction: Vol. 25, No. 5
}

The affiliation for Marie E. Killerby was listed incorrectly in Risk Factors for MERS-CoV Seropositivity among Animal Market and Slaughterhouse Workers, Abu Dhabi, United Arab Emirates, 2014-2017 (A. Khudhair et al.). Dr. Killerby is affiliated only with the Centers for Disease Control and Prevention (Atlanta, GA, USA). The article has been corrected online (https://wwwnc.cdc.gov/eid/ article/25/5/18-1728_article).

\section{Get the content you want delivered to your inbox.}

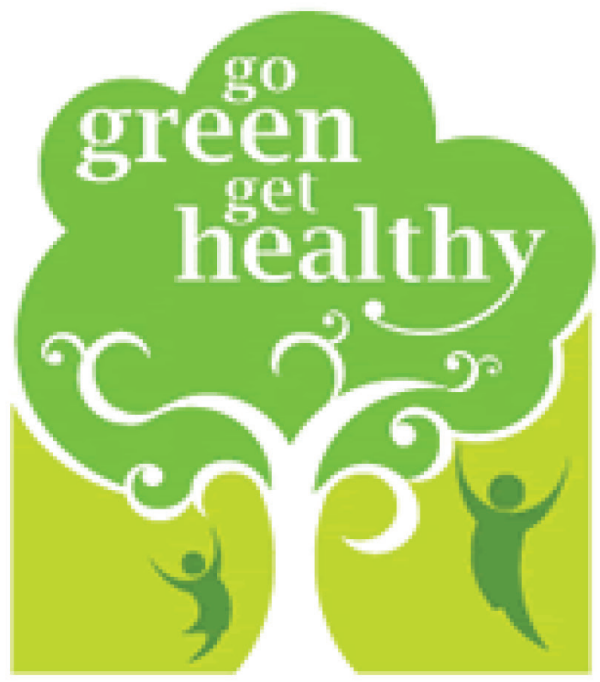

- Table of Contents

- Podcasts

- Ahead of Print articles

- CME

- Specialized Content

\section{Online subscription: wwwnc.cdc.gov/eid/subscribe/htm}

